\title{
A verdade é doce: estudo e tradução de "As Graças ou Hierão", Idílio 16 de Teócrito de Siracusa
}

\author{
Érico Nogueira ${ }^{1}$
}

\begin{abstract}
Resumo: Antes de apresentar tradução em versos hexatônicos do Idílio 16 de Teócrito de Siracusa, "As Graças ou Hierão", analiso neste artigo como num poema idílico se efetiva o encômio a Hierão de Siracusa, de quem Teócrito buscava proteção. As Graças, que personificam a poesia de Teócrito, queixam-se, na metade inicial do poema, da bumilhação que sofreram por não obter protetor. Indignado o poeta investe contra os insensiveis mirando a atenção de Hierão, que estava na iminência de guerrear contras os cartagineses. $O$ verso bexatônico refaz os seis ictos do hexâmetro datílico antigo, sem a rigidez. de outras importantes tentativas de refažer o bexâmetro em português, como as de Carlos Alberto Nunes.
\end{abstract}

Palavras-chave: Teócrito de Siracusa; Idílio 16; teoria da tradução; verso hexatônico; poesia grega helenística.

"As Graças ou Hierão", idílio décimo sexto de Teócrito, conquanto - e com toda a justiça - apreciado por Gow como um dos mais notáveis da lavra do autor $^{2}$, nem tem recebido a devida atenção, por parte da crítica especializada ${ }^{3}$, nem, além disso, tratando-se de poema laudatório, parece ter nada a ver com verdade

1 Este artigo é versão modificada de "A doce elocução", seção que integra a primeira parte de nossa tese de doutorado. Nela traduzimos no mesmo metro que o Idílio 16 todos os idílios hexamétricos autênticos de Teócrito. Cf. NOGUEIRA (2012), pp. 82-100.

2 Cf. ad hoc GOW (1952), vol. 1, p. 305.

3 Cf. AHO (2007), pp. 28-49, que nos oferece um minucioso apanhado da fortuna crítica do idílio - a qual, via de regra, e provavelmente por tratar-se de poema laudatório, não lhe confere status condigno com a sua importância. Situação, aliás, algo semelhante à do livro quarto das Odes de Horácio, descrita por PUTNAM (1986), p. 9, da seguinte maneira: “... Horace's final gathering still suffers faint critical praise. The source of this disquiet is Suetonius' life of the poet, which, to all appearances, finds him yielding to Augustus' desire for Roman epinicia in his honor". 
e doçura ${ }^{4}$, assunto destas linhas. As aparências, porém, enganam, como sabemos, e o fato de o mesmo Píndaro, a quem o Teócrito d' "As Graças" segue de perto, associar tais deusas justamente com a doçura é um bom argumento para incluir alguns aspectos do poema - sendo as Graças a própria personificação de sua poética - num breve estudo, como este, devotado à relação entre elogio, verdade e doçura, no programa poético de Teócrito.

Desde já, assim como o exórdio do idílio primeiro, por exemplo, composto de dois pequenos elogios recíprocos, cuida logo em especificar a precisa estatura poética dos elogiados, abaixo de Pã e das Musas, assim também o exórdio do décimo sexto, aparente elogio do general Hierão, especifica no ato a estatura do narrador - $\mathrm{e}$, com ele, a do general -, no tocante às Musas e aos deuses, respectivamente (vv. 1-4):

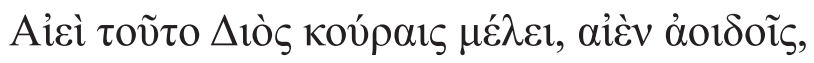

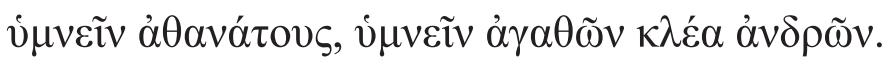

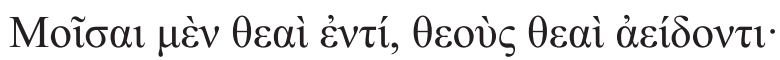

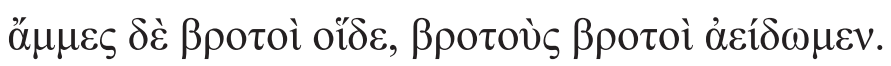

Sempre ocorre às filhas de Zeus, e sempre aos poetas, hinos aos deuses compor, e ao nome dos homens melhores.

Ora, as Musas são divas, e, divas, os divos decantam; nós, mortais como somos, cantemos, mortais, os mortais

Estranha declaração de intenções, sem dúvida. Quando mais não seja, porque não se espera de um encômio tradicional, à maneira de Píndaro ou de Simônides, que distinga claramente, e logo nas primeiras linhas, entre, de um lado, Musas e deuses, poetas e mortais, do outro - ou, em outras palavras, entre os que, divinos, são matéria de divino canto, e os humanos que cabe a humanos celebrar. Eis o ponto: embora os sejam versos francamente laudatórios, patenteiam um piedoso respeito pela hierarquia natural que, bem ao gosto helênico, discrimina entre deuses e homens, e a circunstância nada fortuita de ser este, ao menos em

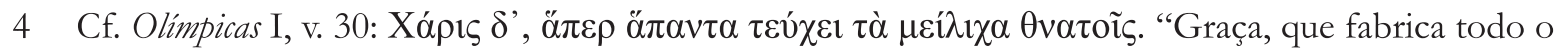
melífluo para os mortais" E também Olímpicas XIV, vv. 4-6: Xá

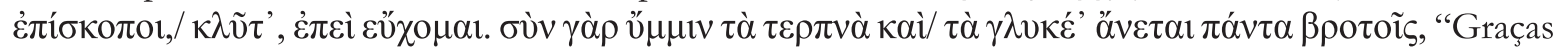
de Orcômeno, sentinelas dos antigos mínios, ouvi, que vos rogo: convosco se perfaz todo deleite e doçura para os homens". 
parte, um poema dedicado aos louvores de Hierão nos mostra que o elogio dos mortais, em Teócrito, costuma ser medido e mediado por honesta apreciação do humano engenho e da humana natureza. Não por acaso, com efeito, ao escrever o encômio de Ptolomeu Filadelfo (um mortal quase imortal, e, pois, de tão subido, um assunto incongruente com sua musa diminuta), o poeta pede logo o auxílio de Zeus, divindade sem dúvida capaz de elevar-lhe o estro a altura condigna daquele a que chama "o mais excelente dos homens" - expediente este, por seu turno, o de invocar o próprio Zeus, para lograr a sua empresa, que em Teócrito não é mera convenção encomiástica, nem exclusivo aceno aos gêneros da elocução, e à relativa superioridade do encômio sobre a bucólica ${ }^{6}$, senão também, haja vista a importância de certa verdade "socrática" em sua poesia", uma demonstração de autoconhecimento, e de justa apreciação da própria arte, que não lhe parece apropriada a executar tarefa tamanha, se não for assistida pelo pai dos deuses.

"As Graças ou Hierão" divide-se em duas partes desiguais, a primeira e maior dedicada àquelas, a este último a segunda. Ora, depois de bem-humorada menção ao choro das Graças, personificação de sua poesia, quando rejeitadas por patronos cujo favor buscaram em vão (vv. 5-12), e de irônico lamento pela avareza dos contemporâneos, que se escusam de subsidiar o poeta (vv. 13-21), Teócrito passa à descrição do patrono perfeito (vv. 22-33) e, em seguida - um dos passos mais extensos e importantes do poema (vv. 34-59) -, à exaltação do poder imortalizador da palavra poética, a única capaz de guardar a memória da gente ilustre (vv. 34-57), e, portanto, de dar aos homens a devida fama após a morte (vv. 58-59). Observe-se então, em primeiro lugar, que a presença do porqueiro Eumeu e do vaqueiro Filécio entre essa gente ilustre (vv. 54-56) vale possivelmente por um pequeno manifesto, uma vez que a humilde e, digamo-lo sem pejo, bucólica condição de ambos, destoando da grandeza das outras personagens, mas ainda

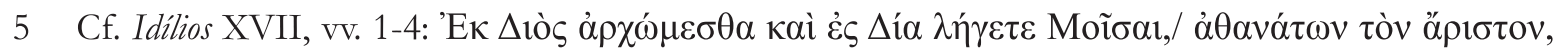

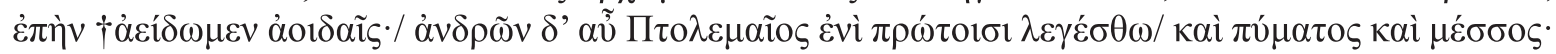

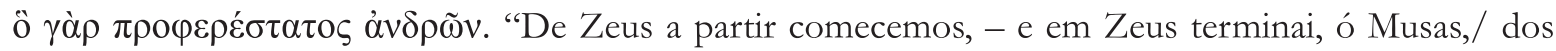
imortais o melhor, quando nossas canções entoamos:/ dos homens, porém, Ptolomeu primeiramente e ao final e/ no meio se diga também: pois é o mais excelente dos homens".

6 Para a relação entre bucólica e encômio, cf. Virgílio, Bucólicas IV, vv. 1-3: Sicelides Musae, paulo maiora canamus!/ non omnis arbusta iunant, bumilesque myricae;/ si canimus siluas, siluae sint consule dignae, "Sículas Musas, cantemos um pouco mais alto! Arbustos não agradam a todos, nem tamarindos humildes; se cantamos florestas, sejam dignas de um cônsul". Muito a propósito, aliás, os estudiosos relacionam esta écloga justamente com o Encômio a Ptolomeu, de Teócrito; cf., p. ex., HARDIE (1998), p. 8: "Eclogue 4 is the least pastoral of the Eclogues, but it has an important Theocritean model in Idyll 17, a hexameter encomium of Ptolemy II".

7 Cf. NOGUEIRA, op. cit., pp. 15-44. 
assim suficientemente digna para merecer figurar na Odisseia ${ }^{8}$, é emblemática da poesia do autor, a qual, conquanto humilde, continua a ser epos ${ }^{9}$, e pode, pois, dentro de limites relativamente exíguos, continuar o legado homérico de eternizar por meio do canto. Além disso, a sentença com que Teócrito remata todo o passo (vv. 73-75), e com ele a primeira parte do poema, é tudo, menos convencional, e, imediatamente anterior ao elogio de Hierão de Siracusa, soa antes como advertência que como loa - com efeito, se apenas e tão-somente um Aquiles ou um Ajaz têm necessidade do poeta, é como se Teócrito lhe dissesse "És tu que precisa de mim, não eu de ti", ou, quando menos, é como se justificasse de antemão uma possível recusa da parte do general, que, não sendo Ajaz nem Aquiles, de facto não precisa de poeta que lhe cante as façanhas.

Situação no mínimo embaraçosa, pois, esta de Hierão; se contrata o poeta, tem de mostrar-se um herói; se o despede sem nada, confessa não sê-lo. E aqui, a despeito da habilíssima manipulação retórica das alternativas, claro, por demais evidente para não ser percebida, o que faz o poeta é pouco mais ou menos exigir do elogiado a mesma honesta apreciação de si, e de seu real valor, como general, que a que exige de si próprio, como poeta. Exigência nada fácil de cumprir, como sabemos, mas, ainda assim, essencial para que a prática do encômio, no encalço da bucólica e de toda a restante poesia do autor, enfim, possa também ela pretender-se verdadeira.

É por isso que o elogio de Hierão de Siracusa, que àquela altura se preparava ainda para uma campanha contra os cartagineses, não é senão um elogio futuro, daquilo que, com a ajuda de Zeus, Atena e Perséfone (vv. 82-84), está por fazer-se, decerto, mas todavia não se fez, e cujo núcleo é a descrição da paz que há de suceder o combate, a qual não por acaso se resolve em detalhada cena bucólica. Nela veem-se campos em flor (v. 90), ovelhas (vv. 90-92), vacas (vv. 92-93), lavouras (vv. 93), e esta que é possivelmente a mais bela imagem do poema, em que a cigarra estrila no alto dos ramos, vigiando os pastores embaixo (vv. 94-96), e aranhas estendem delicada teia por cima de armas tornadas inúteis (vv. 96-97). O recado é claro, e se insere na tradição dos Trabalhos e Dias, que continua e leva além: ao

\footnotetext{
8 Cf. Odisseia XXIII, vv. 366-372.

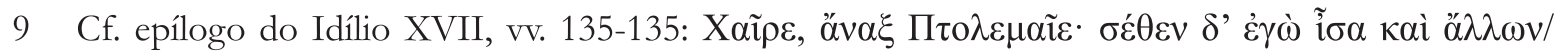

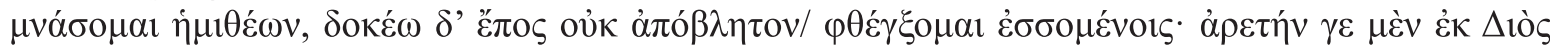

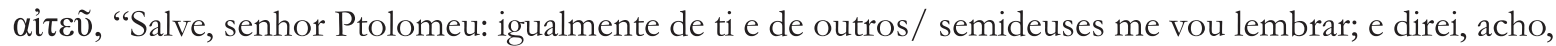
gesta/ aos pósteros não desprezível; mas roga a Zeus por virtude". A circunstância de o termo técnico 'epos', que traduzimos por 'gesta', ocorrer justamente nesse poema não nos parece casual; cf. ad hoc GOW, op. cit., p. 325: "Id. 17 is framed on the pattern of a Homeric Hymn and its audible echoes come from epic, not from the writers of epinician odes".
} 
lado (ou, para sermos exatos, abaixo) da epopeia guerreira, há uma poesia, digamos, pacífica que imortaliza matéria humilde, sim, mas cujo assunto principal, iconizado no trilo da cigarra e nas finíssimas teias de aranha, não é senão o próprio canto. Eis por que, depois da descrição da paz, e da subtil autoafirmação dessa poesia pacífica, ocupada consigo mesma, o poeta volta à consideração de suas Graças, e termina isto que era pra ser um encômio com uma insólita declaração de amor.

Com efeito, após imaginar a glória futura de Hierão decantada por muitos cantores, dos quais é apenas mais um ${ }^{10}$, o narrador invoca as Graças em versos francamente alusivos (vv. 104-105) à décima quarta das Olímpicas, em que não por acaso o tebano vê nelas a causa de toda humana doçura ${ }^{11}$. Se assim é, e se as Graças é a poesia do narrador personificada, a sua recompensa está dada de antemão, no simples fato de ser poeta, e ele realmente não precisa, nem de Hierão de Siracusa, nem de qualquer outro patrono. É por isso que, não sem uma pitada de orgulho, força é convir, o narrador conclui dizendo irá apenas aonde for chamado, uma vez que em casa, onde, presume-se, podem encontrá-lo facilmente, se preciso for, ele já vive pleno dos dons dessas Graças, sem as quais não tem nada amorável na vida, e das quais, enfim, roga nunca se separe (vv. 108-109). E, justamente com isso de amor e de doçura, concluamos esta breve apresentação do poema, e falemos um pouco de nossos critérios de tradução.

\section{Teócrito em verso português}

A estreia de Teócrito na poesia lusófona se deve ao feito pioneiro de Antônio Ferreira, que em muitos passos de suas doze éclogas emulou, imitou e traduziu alguns versos do poeta siracusano ${ }^{12}$. Exceptuando, porém, as alusões eruditas e as traduções parciais ${ }^{13}$, é preciso dizer que os idílios de Teócrito, até há pouco mais de cem anos, praticamente não tinham existência poética em português. De fato, não fosse a tradução decassilábica do idílio de número vinte e sete publicada por Álvaro de Múcio Teixeira no final do século XIX ${ }^{14}$, e a heptassilábica dos de número sete e dez que Henrique Lopes de Mendonça publicou no início do XX ${ }^{15}$,

10 O mesmo mote foi glosado por Horácio, referindo-se evidentemente a Augusto, na ode IV, 2, vv. 41-48.

11 Cf. acima nota 4.

12 Cf. ROCHA PEREIRA (1959-60), pp. 95-110.

13 Cf. passim SIMÕES RODRIGUES (2000).

14 Cf. Idem, pp. 165-173.

15 Cf. Idem, pp. 73-87; 101-107. 
não havia, em português, tradução poética integral de nenhum idílio de Teócrito até 2006, quando Frederico Lourenço incluiu excelentes traduções em verso livre do idílio primeiro, sétimo e undécimo num seu volume dedicado à poesia grega ${ }^{16}$. Professor da Universidade de Coimbra e tradutor de competência comprovada ${ }^{17}$, não há dúvida de que essas traduções de Lourenço, conquanto limitadas a três idílios, hajam chamado a atenção do público especializado e não especializado para a poesia de Teócrito.

Dessa maneira, a tradução que aqui reapresentamos em formato de artigo é nova no fundo e na forma. No fundo, porque é a primeira tradução vernácula do idílio décimo sexto; na forma, porque o verso que empregamos é uma versão lusófona do hexâmetro grego e latino.

Ora, evitando, na medida do possível, repetir o que já dissemos alhures sobre a história da aclimatação do hexâmetro ao português ${ }^{18}$, é preciso dizer que essa história se divide em duas fases, e remonta, na primeira delas, ao século XVIII, e à produção pioneira de José Anastácio da Cunha ${ }^{19}$. Continua, século XIX adentro, com Vicente Pedro Nolasco da Cunha ${ }^{20}$, e, passando por outros nomes, chega, ainda no mesmo século, a Júlio de Castilho ${ }^{21}$, que inaugura sua segunda fase. Tanto quanto pudemos averiguar, os princípios prosódicos utilizados por Castilho têm orientado, desde então, a quase totalidade das empresas do gênero ${ }^{22}$, incluindo a maior e mais importante de todas, que é a tradução hexamétrica da Ilíada, Odisseia e Eneida, de Carlos Alberto Nunes.

Muito brevemente, o que distingue as duas fases entre si é o método que poetas e tradutores empregam na aclimatação do hexâmetro. Na primeira, trata-se ou bem de seguir as regras métrico-prosódicas do latim, língua-mãe do português, fundadas na quantidade silábica (o método de Anastácio), ou bem de estabelecer teoricamente e poetar de fato com quantidades silábicas supostamente portuguesas (o método de Nolasco). Na segunda, a regra é, digamos, transpor a prosódia clássica na vernácula, interpretando a sílaba longa grega ou latina como tônica ou

16 Cf. LOURENÇO (2006).

17 Entre outras traduções de sua lavra, destaquem-se a Ilíada e a Odisseia de Homero, ambas lançadas no Brasil pela Companhia das Letras.

18 Cf. OLIVA NETO \& NOGUEIRA (2013).

19 Cf. passim J. A. DA CUNHA (2006).

20 Cf. V. P. NOLASCO DA CUNHA (1815a; 1815b; 1813).

21 Cf. CASTILHO (1874), pp. 29-32.

22 Para uma lista mais ou menos completa dessas empresas, vide OLIVA NETO \& NOGUEIRA (2013), p. 307 , nota 68. 
subtônica portuguesa, e como átona a sílaba breve - e isso ou por justaposição de metros vernáculos tradicionais, como o hexâmetro de Magalhães de Azeredo ${ }^{23}$; já pelo rigoroso encadeamento de células dactílicas, como o hexâmetro de Carlos Alberto Nunes; já pela combinação de células dactílicas e trocaicas, enfim, que é o método que utilizamos.

Voltando ao idílio em questão, a alegada insistência na doçura - traço que o leitor poderá constatar em breve, esperamos, ao ler a tradução abaixo - vale pelo charme sensível tão da poesia do autor, e que nela não serve a interesses escusos, digamos, senão, muito pelo contrário, é o expediente elocutório mais apto a despertar leitor ou ouvinte para a verdade que aí se anuncia. Desse modo, nossa tradução procurou equivalentes vernáculos para os valores sensíveis que destacamos na seção anterior, inclusive as variações rítmicas do original, que buscamos reproduzir. Não contando com quantidade silábica, o verso vernáculo que cunhamos não é nem podia ser um hexâmetro propriamente dito, razão por que o temos chamado, à falta de melhor nome, "verso hexatônico". Como o compreendemos e praticamos, pois, este verso é sucessão variada de seis células rítmicas dactílicas ou trocaicas (mas preponderantemente dactílicas), com possibilidade de anacruse na primeira sede e de fim de verso agudo, grave ou esdrúxulo, contabilizando sempre seis tônicas por linha. Não se trata, contudo, de considerar as palavras e suas tônicas isoladamente, senão de encarecer a tonicidade, dir-se-ia, natural de uma prolação contínua de vocábulos portugueses, segundo os grupos de força estudados por Mattoso Câmara ${ }^{24}$.

Finalmente, tratando-se de verso cuja regularidade assenta no número de tônicas, mas cujas sílabas podem variar de doze a dezoito, o hexatônico é flexível e maleável o bastante para acompanhar de perto a reconhecida sofisticação do hexâmetro de Teócrito ${ }^{25}$, e para reproduzir mediante o som e a distribuição das palavras no espaço o que as mesmas palavras estão a descrever ou sugerir. Senão vejamos:

\section{Texto do Idílio 16 de Teócrito de Siracusa}

\section{XAPITE $\Sigma$ H IEP $\Omega N$}

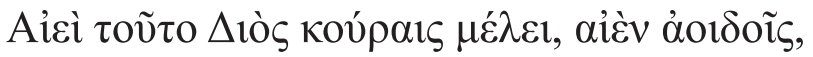

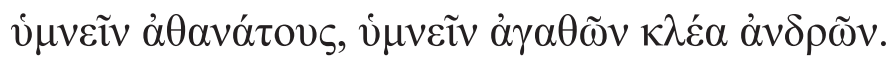

23 Cf. MAGALHÃES DE AZEREDO (1904), p. 59.

24 Cf. MATTOSO CÂMARA JR. (1985), pp. 36-39.

25 CF. FANTUZZI (1995). 


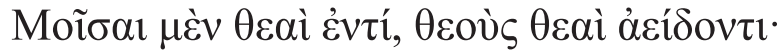

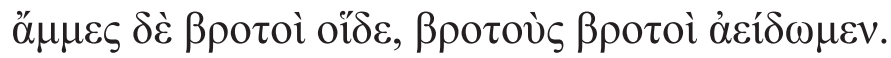

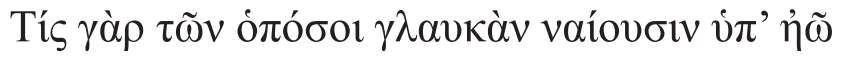

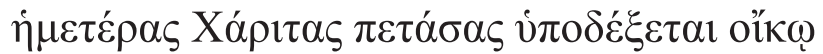

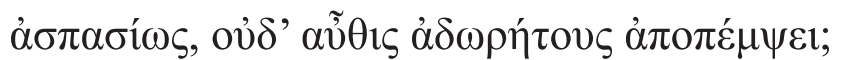

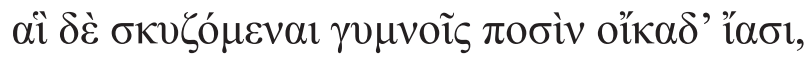

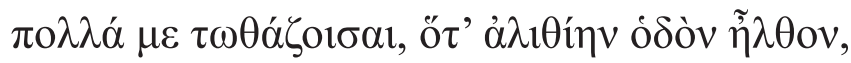

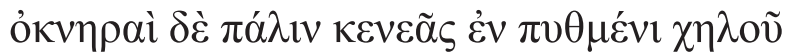

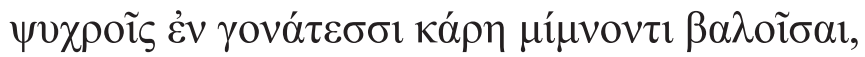

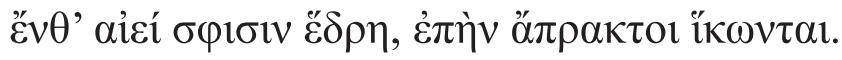

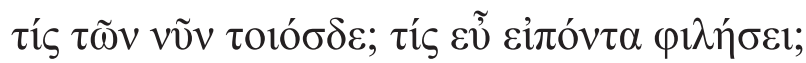

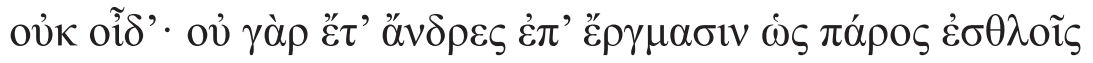

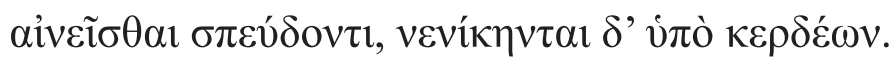

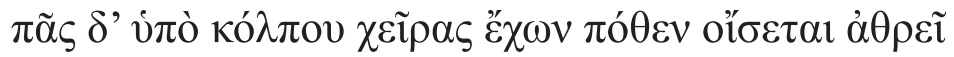

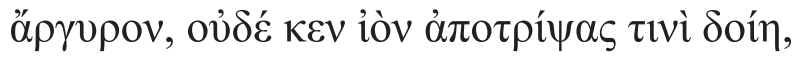

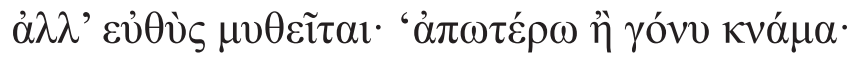

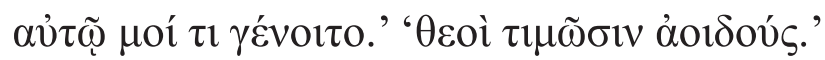

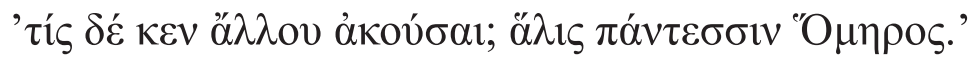

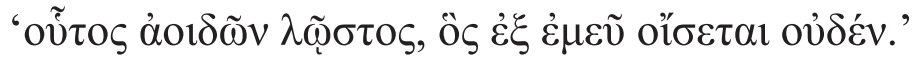

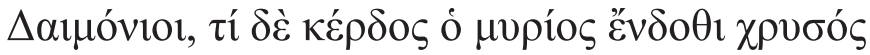

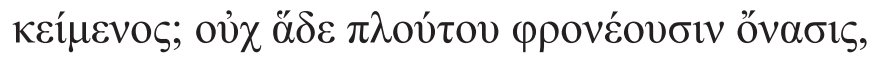

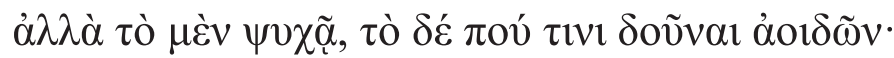

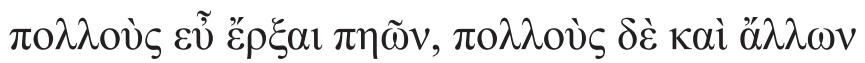

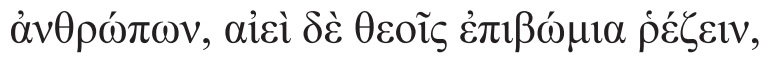

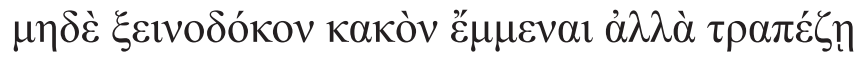

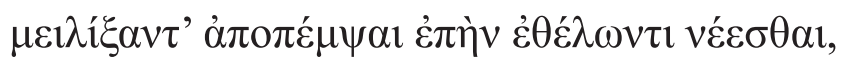

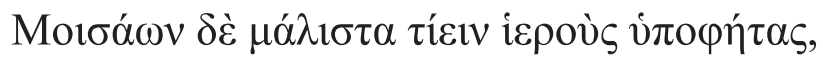

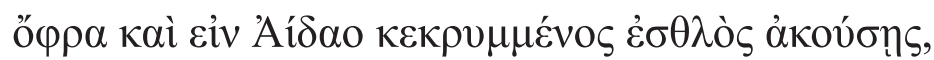

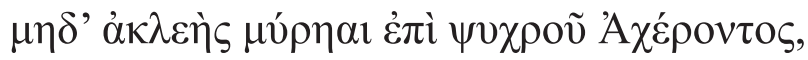

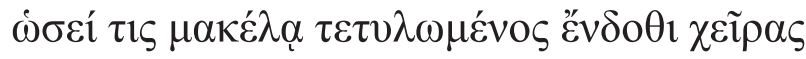

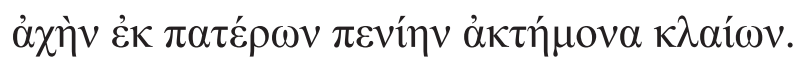

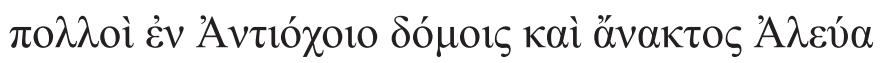

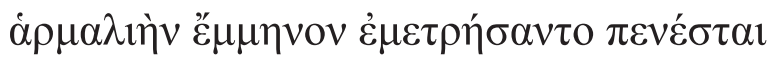

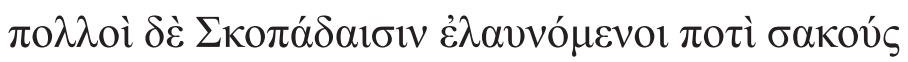




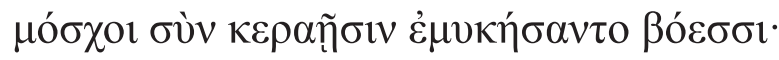

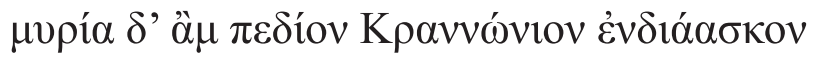

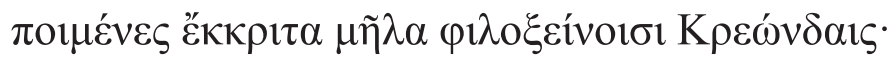

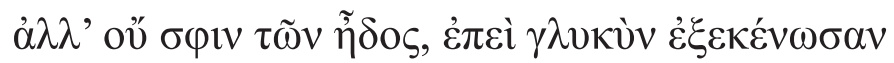

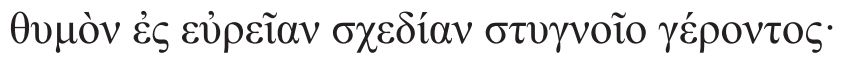

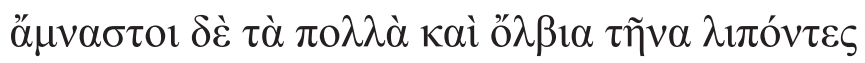

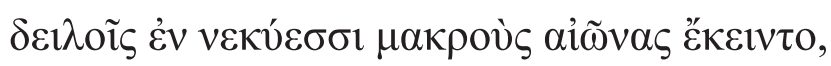

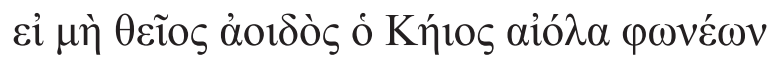

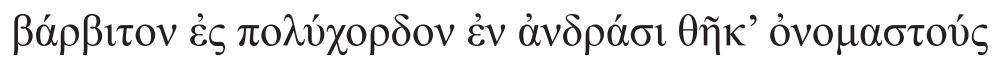

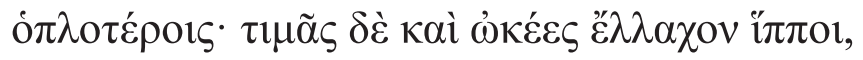

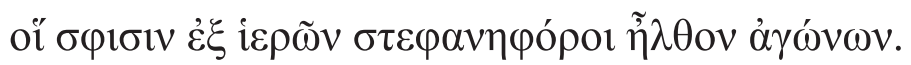

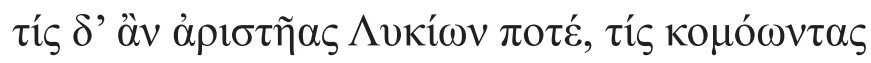

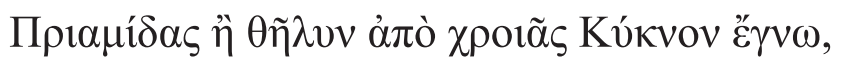

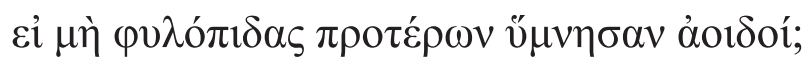

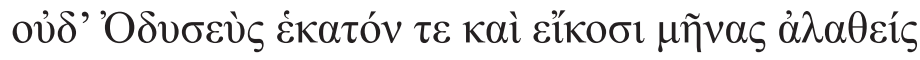

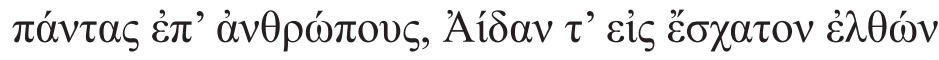

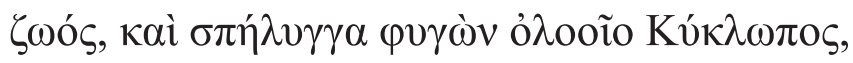

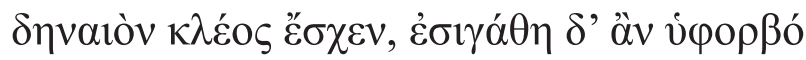

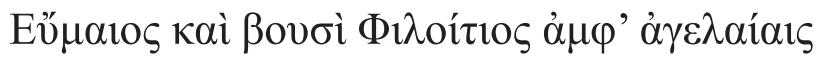

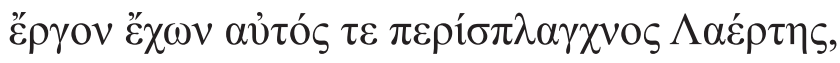

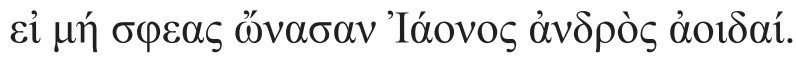

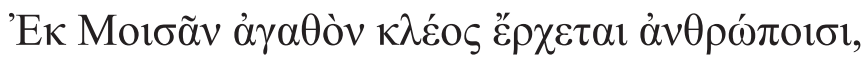

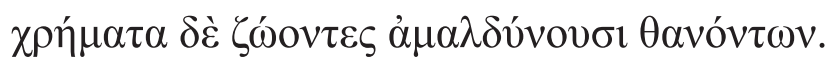

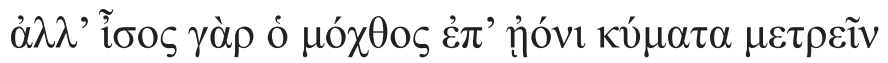

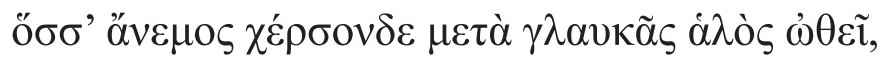

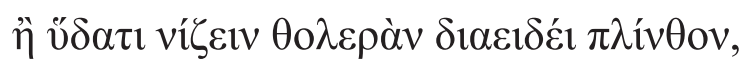

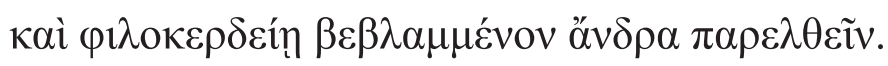

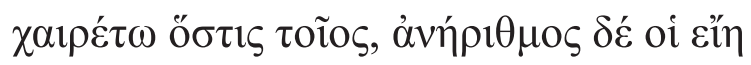

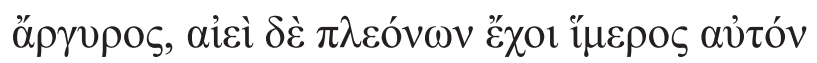

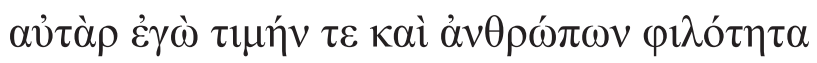

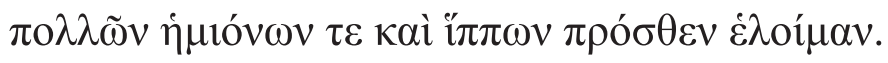

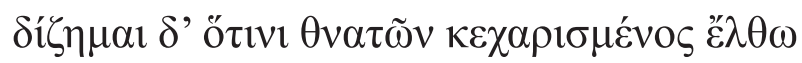

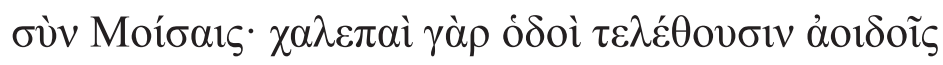

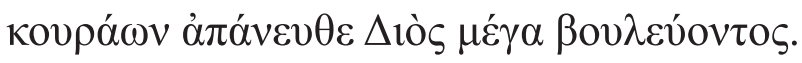




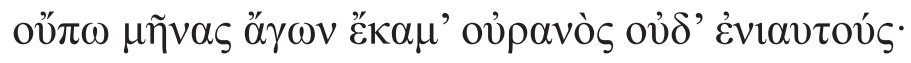

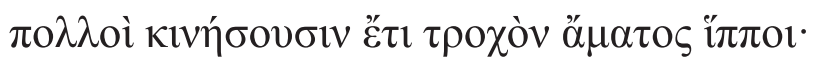

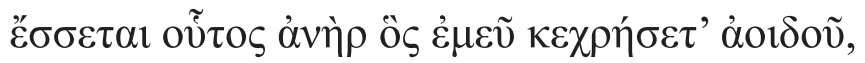

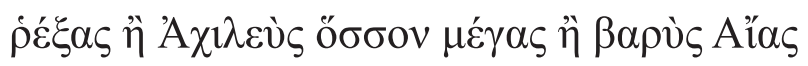

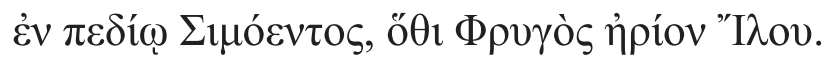

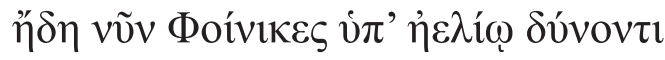

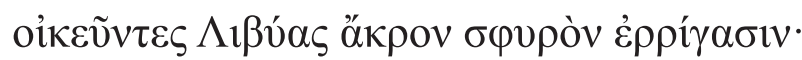

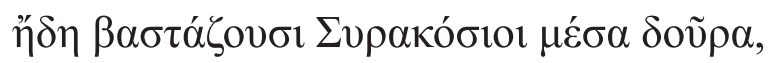

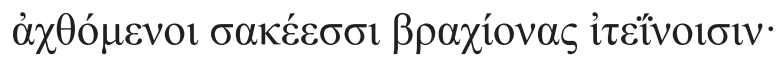

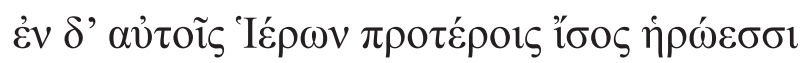

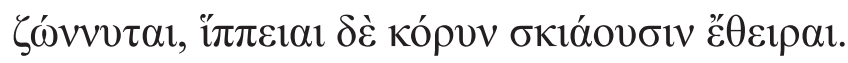

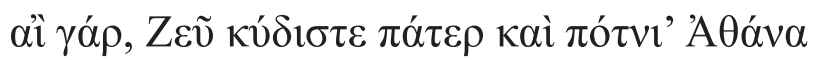

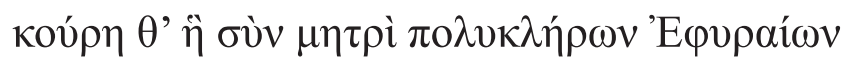

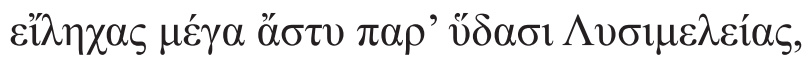

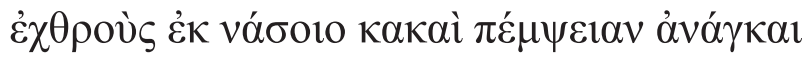

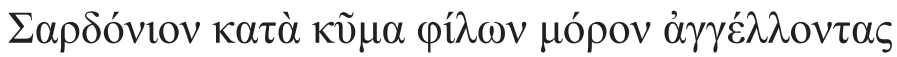

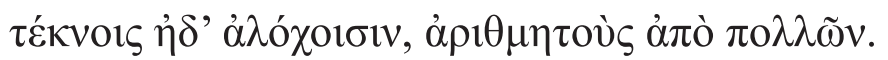

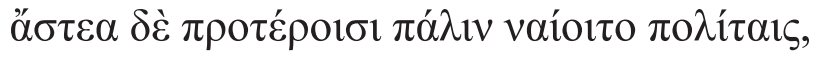

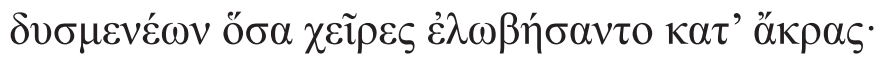

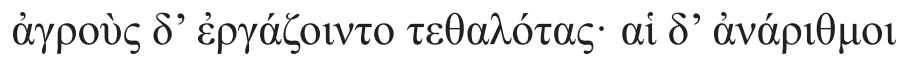

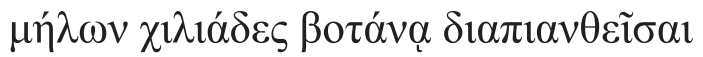

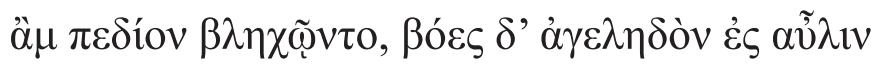

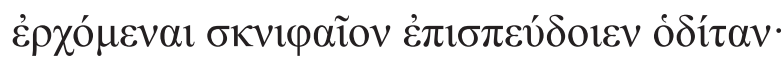

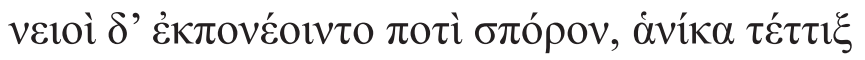

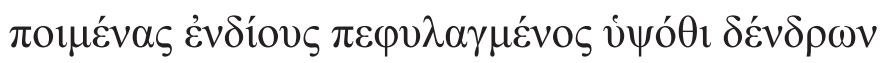

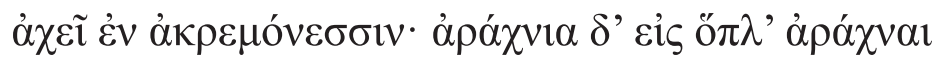

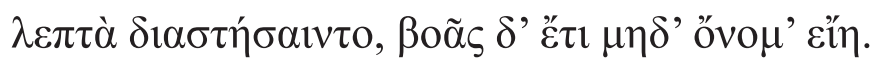

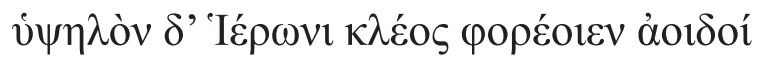

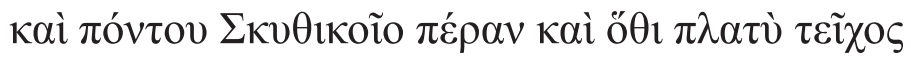

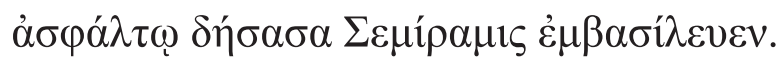

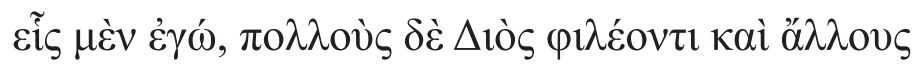

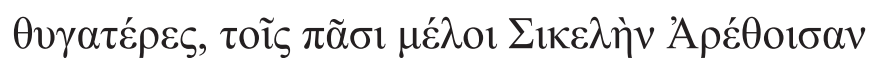

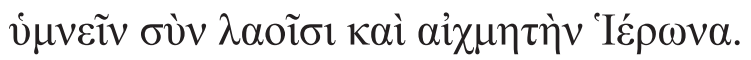

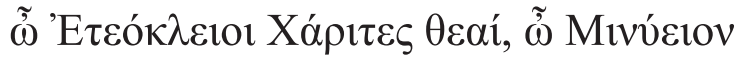




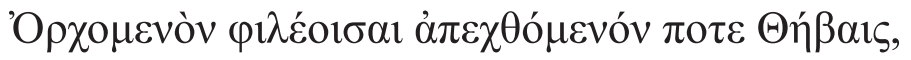

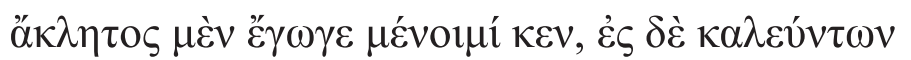

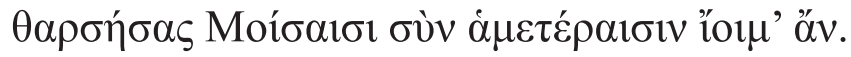

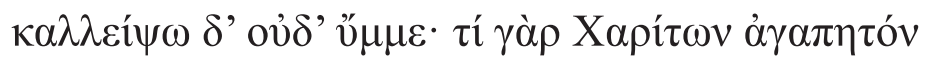

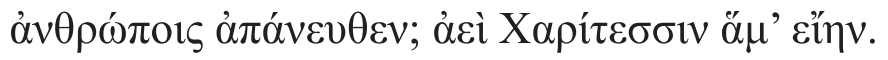

\section{Tradução do Idílio 16, de Teócrito de Siracusa}

\section{As Graças on Hierão ${ }^{26}$}

Sempre ocorre às filhas de Zeus, e sempre aos poetas,

hinos aos deuses compor, e às proezas dos homens melhores.

Ora, as Musas são divas, e, divas, os divos decantam;

nós, mortais como somos, cantemos, mortais, os mortais.

Mas quem, de quantos habitam debaixo da lúcida aurora,

irá minhas $\mathrm{Graças}^{27}$ de braços abertos em casa acolher

benevolamente, e não despedi-las sem prenda nenhuma?

As quais, resmungando, de pés descalços pra casa retornam,

mui mal falando de mim, porque um vão caminho fizeram,

e, tímidas, mais uma vez no fundo do cofre vazio,

metendo a cara entre os frios joelhos, então permanecem, onde é o seu lugar sempre quando voltam de mãos abanando ${ }^{28}$.

Quem hoje em dia é tal, que amará a quem o bendiga?

Não sei; pois os homens não mais, como antes, por que lhes celebrem

os feitos ilustres se afanam, vencidos que estão pelo lucro ${ }^{29}$.

26 Este poema pode dividir-se em duas grandes seções: procura e descrição do patrono ideal (1-75) e elogio de Hierão II de Siracusa (76-109). Engenhosamente construído, mesclando elementos tanto da lírica - em especial de Simônides e Píndaro - como da épica, o idílio pode dizer-se um dos mais belos e bem acabados da lavra do autor.

27 As Graças, neste idílio, personificam a poesia de Teócrito, em geral, e, em particular, os dons que essa mesma poesia confere.

28 Cf. ad hoc PALUMBO STRACCA (2004), p. 272: "Alla base dell'immagine nello scrigno c'è un aneddoto riguardante Simonide, che ci è stato da Stobeo (III. 10, 38). Simonide diceva di avere una cassa per le $\chi \alpha ́ p ı \tau \varepsilon \varsigma$ (da intendere nel senso di 'riconoscenza'), e un'altra per il denaro; aggiungeva, poi, che quando apriva la cassa delle $\chi \alpha ́ \rho ı \tau \varepsilon \varsigma$, non vi trovava nulla di utile. Per la verità, l'aneddoto simonideo è solo uno spunto, e la situazione prospettata da Teocrito è piuttosto quella dei rotoli di papiro contenenti i suoi scritti, che rimangono tristemente a giacere nelle casse, perché non interessano ad alcuno".

29 O mesmo mote é glosado por Petrarca no famoso primeiro terceto do soneto VII: "Qual vaghezza di lauro, qual di mirto?/ Povera e nuda vai philosophia/ dice la turba al vil guadagno intesa". 
Todos com a mão na algibeira calculam donde hão de tirar a prata, da qual nem ferrugem, polindo, dariam a ninguém, mas logo diriam: "Bem, a canela depois do joelho: antes eu mesmo o tivesse", ou "Os deuses deem glória aos poetas", ou "Quem ouviria um terceiro? Homero é bastante pra todos", ou "Este é o melhor dos poetas: quem nada não leva do meu". Ó venturosos, que lucro haveria no muito ouro guardado? A quem pensa, não é tal da riqueza o proveito, mas dar-se a si mesmo e, quiçá, a um ou outro poeta; e beneficiar a muitos dos seus, e a muito estrangeiro também, e sempre aos deuses, no altar, perpetrar sacrifícios, e nunca ser mau anfitrião, senão obsequioso à mesa, licença ceder quando quer que queiram partir; das Musas, porém, sobretudo honrar os sagrados ministros, para que mesmo sepulto no Hades escutes "Insigne!", nem gemas tampouco sem glória à beira do frio Aqueronte, como um sujeito de mãos calejadas pelo enxadão - um pobre de pobres pais - a chorar a penúria indigente. Muitos, tanto na casa de Antíoco como na de Álevas grão-senhor, com mensal provimento servos contaram; e muitos também, conduzidos ao estábulo, sim, dos Escópadas juntamente com vacas chifrudas, bezerros mugiram; milhares pela planície cranônia de ovelhas seletas ${ }^{30}$ guardavam os pastores para os Creôntidas hospitaleiros: no que não tiveram deleite nenhum, já que a vida, tão doce, es-correram na capacíssima balsa do hórrido velho; e abandonando tanta fartura e abundância, esquecidos entre misérrimos mortos um longo tempo quedaram, se aquele divino poeta de Quios, modulando os seus cantos à lira policórdia, entre os homens vindouros os não

30 Nesse passo, a distância insolitamente grande entre o pronome indefinido "muitos" e, respectivamente, "servos" e "bezerros" - como também entre o substantivo "milhares" e as "ovelhas seletas" que o especificam - é tentativa consciente, da parte do poeta, de achar um como correspondente espacial à grandeza quantitativa que refere. Esse arranjo, digamos, pictórico das palavras no interior dos versos será prática comum entre os poetas latinos do período de Augusto, especialmente em Virgílio. 
fizesse famosos: e honra aos velozes corcéis também houve, os quais coroados das sacras corridas voltaram aos donos.

Quem os chefes dos Lícios jamais conhecera, e os comados Priâmidas quem, ou Cicno, femíneo que era de aspeito, se hinos às guerras dos homens de então não cantassem os poetas? 50 Nem mesmo Odisseu, que cento e vinte meses durante errou por todos os povos, e ao Hades extremo chegou com vida, e escapou da espelunca de certo funesto ciclope, glória durável tivera; e menção não houvera ao porqueiro Eumeu, e a Filécio tampouco, que tanto lidou com o rebanho das vacas, nem muito menos ao próprio Laertes magnânimo, se não lhes valessem a eles do jônio varão as canções. Sim, é das Musas que a boa fama toca aos mortais: dos mortos as posses, porém, são os vivos, oh sim, que dissipam. Igual, com efeito, é o labor de as ondas contar junto à praia, quantas o vento impele com o glauco mar contra a terra, ou com translúcida água lavar um tijolo barrento ${ }^{31}$, - e, pela avareza entrevado, um homem, enfim, convencer. Adeus a quem quer que assim seja, que possa possuir incontável prata, e desejo de mais e mais sempre a ele o arrebate: eu, por meu turno, porém, o respeito e a amizade dos homens de longe a muitos jumentos e a muitos corcéis preferira. Busco um mortal por quem seja bem recebido ao bater a reboque das Musas: aos poetas acabam tortuosas as vias sem as filhas de Zeus de sublimíssimo siso.

O céu inda não se cansou de trazer os meses e os anos, e muitos o carro do dia cavalos ${ }^{32}$ inda hão de puxar; este há de ser o varão que precise de mim o poeta: quem tanto fez quanto Aquiles, o grande, ou o gravíssimo Ajaz na do Simoenta planície, onde é a tumba de Ilo, o troiano. Já os fenícios agora - habitantes, debaixo do sol

31 Dito proverbial.

32 Cf. nota 30. 
poente, da extrema costa da Líbia - tremem de medo ${ }^{33}$;

já os siracusanos brandem o meio das lanças,

pesados ali os seus braços por entre os escudos de vime;

e dentre os primeiros ali Hierão igualzinho a um herói

veste a armadura, e a equina cimeira ensombrece-lhe o elmo.

Ó Zeus, maxíssimo pai, e Atena rainha também,

e tu, ó filha ${ }^{34}$, a quem coube, com a mãe, a magna cidade

dos efireus locupletos ${ }^{35}$, às margens de Lesimelia ${ }^{36}$ :

vicissitudes malignas arrojem da ilha os imigos

ao Mar da Sardenha, e então os que se contam nos dedos, de muitos

que eram, a filhos e esposas o fado dos seus anunciem.

E voltem a povoar as cidades os seus habitantes de antanho,

quantas as mãos inimigas pilharam dos pés à cabeça;

e campos florentes cultivem também; e, além disso, milhares

milheiros de ovelhas, pastando em regime de engorda,

berrem pela planície, e das vacas as juntas, tornando ao

curral, apressem entanto o crepuscular caminheiro;

e a terra em alqueive se lavre pra messe, quando a cigarra, aos

pastores solares vigiando lá de cima das árvores,

trila entre os ramos; e aranhas por cima das armas distendam

subtis aranhóis, e nem nome não fique do grito de guerra ${ }^{37}$.

E a subidíssima glória de Hierão transportem os poetas

para além do Mar Cítico ${ }^{38}$, lá onde larga muralha,

rejuntando de asfalto, Semíramis teve o seu reino ${ }^{39}$.

Sou um, tão-somente; e amam a muitos outros as filhas

33 Descritas as características gerais do patrono ideal, Teócrito se dirige agora, na segunda parte, concreta e singularmente a Hierão, general siracusano que então se preparava para uma campanha contra os cartagineses e seria coroado rei anos depois.

34 Perséfone.

35 Ou seja: Siracusa.

36 Várzea localizada nos arredores de Siracusa.

37 Esse passo, eivado de imagens e vocábulos pastoris, soa como uma espécie de recusatio bucólica da poesia épica, e, por isso mesmo, pode ler-se como uma lição de poesia.

38 Ou seja: o Mar Negro.

39 A Babilônia. 
de Zeus; - mas todos eles cuidem em hinos compor

a Aretusa sícula mais sua gente e o lanceiro Hierão.

Ó deidades de Eteocles, ó Graças! Ó vós que a mínia

Orcômeno amais, um dia odienta que foi para Tebas:

não sendo chamado, que fique eu por cá, mas àqueles que chamam

mui confiante a reboque das minhas Musas atenda.

Não hei de deixar-vos a vós: pois o que de amorável houvera

ao homem sem Graças? Juntinho das Graças pra sempre eu esteja.

\section{Referências}

AHO, L. K. Theocritus' "Graces": Text and Translation, with Introduction and Commentary. Dissertation. University of Iowa. 2007.

CASTILHO, A. F. de. Tratado de Metrificação Portugueza: Seguido de Considerações Sobre a Declamação e a Poetica. 5a ed. revista e augmentada. Porto: Livraria Moré-Editora, 1874.

CUNHA, J. A. da. Obra Literária, 2 volumes, edição de Maria Luísa Malato Borralho e Cristina Alexandra Marinho. Porto: Campo das Letras. Vol. I, 2001; Vol. II, 2006.

FANTUZZI, M. "Variazioni sull'Esametro in Teocrito". In: Struttura e Storia dell' Esametro Greco. Vol. I. Roma: Grupo Editoriale Internazionale, 1995. pp. 221-264.

GOW, A. S. F. (ed.) Theocritus, 2 volumes. Cambridge: Cambridge University Press, 1952.

HARDIE, P. Virgil (Greece \& Rome: New Surveys in the Classics n. 28). Oxford: Oxford University Press, 1998.

LOURENÇO, F. Poesia Grega de Álcman a Teócrito. Lisboa: Cotovia, 2006.

MAGALHÃES DE AZEREDO, C. Odes e Elegias. Roma: Tipografia Centenari, 1904.

MATTOSO CÂMARA JR., J. História e Estrutura da Lingua Portuguesa. Rio de Janeiro: Padrão, 1985.

NOGUEIRA, É. Verdade, Contenda e Poesia nos Idílios de Teócrito. São Paulo: Humanitas, 2012.

NOLASCO DA CUNHA, V. P. “Sobre a Objecção do Snr. Bento Pereira á cerca da 'Syllaba Portugueza"'. In: O Investigador Portuguez, em Inglaterra ou Jornal Literario, Politico. Vol. 14, n. 54, novembro de 1815 a.

“ "Consideraçoens sobre o Verso Saphico, e Principios Geraes da Syllaba, Applicados

Particularmente á Lingoa Portugueza”. In: O Investigador Portuguez em Inglaterra ou Jornal Literario, Politico. Vol. 13, n. 52, outubro de 1815b.

O Investigador Portuguez, em Inglaterra, vol. 7, n. 27, setembro de 1813.

OLIVA NETO, J. A. \& NOGUEIRA, É. “O Hexâmetro Dactílico Vernáculo antes de Carlos Alberto Nunes”. In: Scientia Traductionis 13, julho de 2013. pp. 295-311.

PALUMBO STRACCA, B. (ed.) Teocrito: Idilli e Epigrami. Milano: BUR, 2004. 
84 Érico Nogueira. A verdade é doce: estudo e tradução de "As Graças ou Hierão", Idílio 16 de Teócrito...

PUTNAM, M. C. J. Artifices of Eternity: Horace's Fourth Book of Odes. Ithaca \& London: Cornell University Press, 1986.

ROCHA PEREIRA, M. H. “Alguns Aspectos do Classicismo de António Ferreira". In: Humanitas XI-XII, (1959-1960). pp. 80-111.

SIMÕES RODRIGUES, N. M. Traduções Portuguesas de Teócrito. Lisboa: Universitária, 2000. 